Natasza LUBIK-RECZEK

Uniwersytet im. Adama Mickiewicza w Poznaniu

Rafał RECZEK

Instytut Pamięci Narodowej, Poznań

\title{
Liga Kobiet - organizacja „reprezentująca” interesy kobiet w Polsce Ludowej. Zarys działania
}

$\mathrm{Z}$ akończenie zmagań na arenie wojennej nie dało Polakom upragnionej wolności. Rok 1945 stał się momentem zakończenia II wojny światowej. Polska stała się strefą wpływów polityki Józefa Stalina i de facto jej samodzielność na arenie międzynarodowej uległa znacznemu ograniczeniu, czy wręcz wszystkie najważniejsze decyzje dotyczące polityki wewnętrznej i zewnętrznej były realizacją założeń, jakie w stosunku do Polski miała Moskwa.

Komuniści uważali, że wolność przyniosły Polsce wojska sowieckie i obecnie budując państwo komunistyczne realizujemy jedyną i właściwą wizję sprawiedliwości społecznej, ideę, która wcześniej nie była realizowana.

Wraz z przejęciem władzy w kraju komuniści postawili przed sobą nowe zadania, do najważniejszych $\mathrm{z}$ nich należało utrzymanie władzy i zwalczanie opozycji parlamentarnej, jak i wszelkich przejawów zbrojnego oporu, którego korzenie wywodziły się z formacji Armii Krajowej. W zamysłach „nowej władzy” było również ,przebudowanie” świadomości Polaków i stworzenie „nowego” obywatela (Reczek, 2008a, s. 154).

Komuniści utrwalanie władzy realizowali metodycznie. W pierwszym okresie po odzyskaniu przez Polskę „,niepodległości” i po przejęciu władzy przez komunistów relacje na linii Państwo-Kościół katolicki układały się w miarę poprawnie. Władze do wyborów w roku 1947 nie wystąpiły w sposób zdecydowany przeciw Kościołowi (Kumor, 2001, s. 475).

Wykorzystując fakt, że „nowa” władza musiała okrzepnąć, a przede wszystkim, że była „zajęta” zwalczaniem przeciwników politycznych i skierowała żądła swojej propagandy m.in. przeciwko osobie Stanisława Mikołajczyka i reprezentowanego przez niego Polskiego Stronnictwa Ludowego (PSL). Szczególne nasilenie represji wobec PSL nastapiło 
w okresie akcji politycznej przed wyborami styczniowymi 1947 r. (Stanisław Mikołajczyk, 2010, s. 34).

Tą władzą komuniści nie zamierzali się dzielić z żadnym ugrupowaniem politycznym tj. PPS-em, ani tym bardzie z kierowanym przez Mikołajczyka PSL, jak mówił Władysław Gomułka - „władzy raz zdobytej nie oddamy nigdy" (Łatyński, 2002, s. 319).

W zajmowanych przez Armię Czerwoną miastach Sowieci aresztowali reprezentantów Polskiego Państwa Podziemnego, a następnie ochraniali nowe organy władzy kierowane przez komunistów i ich zwolenników ( $O d$ niepodległości, 2010, s. 208).

Taktyka działania komunistów zaraz po wojnie była dyktowana ich słabością. Możliwość działania zapewniała im w pierwszych kilkunastu miesiącach armia Czerwona, a w kolejnych rozbudowany aparat represji państwa komunistycznego (ibidem, s. 208). Był on jedyną, acz realną siła, mogącą urzeczywistnić wizję PPR-u o zaprowadzeniu w Polsce nowych porządków, a fakt całkowitej zależności zarówno tego aparatu, jak i partii komunistycznej od woli Stalina uniemożliwiał jakikolwiek inny przebieg zdarzeń niż podporządkowanie kraju Moskwie (Wybory do, 2010, s. 25).

W takiej sytuacji politycznej rację bytu miały tylko partie polityczne oraz inne podmioty życia politycznego, które podporządkowały się władzy komunistycznej i które w swych założeniach programowych nie aspirowały do wytyczania nowych kierunków, prądów politycznych i społecznych. Funkcjonując w realiach państwa komunistycznego, zgadzały się one na realizację wizji, którą propagowała lub wskazywała jako właściwą władza ludowa.

Tak było z Ligą Kobiet. Powstała ona w sierpniu 1945 r., została zarejestrowana jako jedna z pierwszych po wojnie - w rejestr organizacji została wpisana pod numerem 35 (Walczewska, 2013). Jak podaje w swym artykule Sławomira Walczewska - „swą nazwą, która w początkowej wersji brzmiała: Społeczno-Obywatelska Liga Kobiet nawiązywała do patriotycznej organizacji kobiecej utworzonej w 1913 roku dla poparcia niepodległościowych dążeń Piłsudskiego. W swoim programie umieściła dwa punkty, pod którymi mogłaby się podpisać każda kobieta: przeciwdziałanie nowej wojnie oraz współpraca w budowie sprawiedliwej Polski. Wizja owej „sprawiedliwej” Polski była przy tym na tyle ogólnie nakreślona, że nie wykluczała z góry żadnych opcji politycznych czy światopoglądowych. Program ten zwiódł kilka organizacji międzywojennych, które chciały się reaktywować po wojnie, takich jak Demokratyczny Klub Kobiet, Liga Kooperatystek, sekcja polska Międzynarodowego Stowarzy- 
szenia Kobiet z Wyższym Wykształceniem Uniwersyteckim, i które zostały wchłonięte przez Ligę Kobiet. Pozornie otwarta na wszystkie inicjatywy kobiece, stanowiąca forum organizacji kobiecych, Liga Kobiet w końcu lat 40-tych i na początku 50-tych wywierała już wyraźny, silny nacisk ideologiczny na swoje członkinie. O żadnej autonomii reaktywowanych stowarzyszeń nie mogło być mowy. LK zapewniła sobie wyłączność na wszystkie inicjatywy kobiece i realizowała zadanie, dla jakiego została stworzona: włączenie, a raczej wmanipulowanie kobiet w przemiany ustrojowe" (ibidem).

Liga powielała, a może raczej odwzorowała model działania podobny do mechanizmu przejmowania władzy przez komunistów. Odwoływała się do haseł, które trafiały do wielu środowisk kobiecych. Jak trafnie podaje przywołana już Sławomira Walczewska „Idee aktywizacji zawodowej i politycznej kobiet, głoszone przez Ligę Kobiet, zgodne były z ideą emancypacji kobiet i jako takie mogłyby zapewne zostać poparte przez aktywistki przedwojennego ruchu kobiecego, który stanowił szerokie spektrum ponad 80 organizacji kobiecych oraz kobiecych instytucji" (Walczewska, 2013). Realizując swoje założenia o stworzeniu jednej organizacji, która będzie skupiała wszystkie środowiska kobiece, Liga dopuściła początkowo do sytuacji, w której w ideę powstania ruchu kobiecego włączało się wiele przedwojennych środowisk kobiecych. Był to niestety tylko zabieg propagandowy mający na celu pozyskanie akceptacji największej możliwej liczby kobiet i środowisk je reprezentujących, które legitymizowały będą nową organizację kobieca, zależną od komunistów, a nie rzeczywiste zainteresowanie stworzeniem szerokiej platformy ruchu kobiecego.

Dowodem potwierdzającym intencje założycielek organizacji był skład założycielek Ligi Kobiet, wśród członkiń których nie było nazwisk przedwojennych działaczek kobiecych, jak również działaczek przedwojennej Społeczno-Obywatelskiej Ligi Kobiet (ibidem).

Skład założycielek Ligi Kobiet był charakterystyczny dla ówczesnego układu sił politycznych w Polsce i jednoznacznie wskazywał, kto będzie siłą dominująca i kto będzie wytyczał kierunki działania tej organizacji kobiecej. Wśród założycielek znalazły się więc: trzy komunistki z Polskiej Partii Robotniczej (PPR) - Irena Płotnicka, Felicja Fornalska, Mara Turlejska, dwie socjalistki z Polskiej Partii Socjalistycznej (PPS) - Eugenia Pragierowa, Regina Fuszarowa, jedna działaczka ruchu ludowego z Polskiego Stronnictwa Ludowego (PSL) - Stanisława Garncarczyk, jedna demokratka reprezentująca Stronnictwo Demokratyczne (SD) - Maria Jaszczukowa (ibidem). Jak podaje Sławomira Walczewska „bezpartyjna 
była jedynie przewodnicząca Zarządu, Irena Sztachelska: w czasie wojny była ona oficerem politycznym I Armii LWP” (ibidem). „Bezpartyjność” przewodniczącej Zarządu Ligi Kobiet, Ireny Sztachelskiej (żony działacza komunistycznego Jerzego Sztachelskiego) była tylko iluzoryczna. Osoba stojąca na czele organizacji, której funkcjonowanie uzależnione było od realizacji zaleceń władzy, musiała mieć poparcie władzy i być tej władzy posłuszna.

Komuniści, kreując nową rzeczywistość polityczną i społeczną w Polsce, po dojściu do władzy starali się pozyskiwać poparcie społeczne, tak by nową władzę legitymizować. Wykorzystywali do tego celu wszelkie zabiegi propagandowe i manipulacje. Poczynając od niekonfrontacyjnej polityki układania stosunków z Kościołem katolickim, po tworzenie najmniejszych instancji i organizacji społecznych. Do osiagnięcia celu, którym było pełne podporządkowanie społeczeństwa i przejęcie pełnej kontroli nad wszystkimi elementami życia społeczno-politycznego, komuniści robili gesty dobrej woli, które z uczciwością miały niewiele wspólnego. Tak samo było w przypadku Ligi Kobiet.

„Początkowe deklaracje Ligi, że chce być organizacją dla wszystkich Polek, były zabiegiem propagandowym, mającym na celu skupienie w swych szeregach największej liczby kobiet. Stan świadomości politycznej kobiet, stopień zaangażowania się przez nie w tworzenie nowego ustroju, był przedmiotem intensywnych zabiegów Partii. Przy KC PZPR istniał nawet Wydział Kobiecy, którego szefowa, Orłowska, oddelegowała w 1951 swoją podwładną, Alicję Musiałowa, do przejęcia funkcji przewodniczącej Ligi Kobiet, „wybranej” na pierwszym ogólnopolskim zjeździe w 1951 roku" (ibidem).

Jak wyglądało tworzenie Ligi Kobiet. Jej członkiem mogła zostać każda kobieta lub grupa kobiet (Koła Gospodyń Wiejskich, Koła Spółdzielczyń), która uznawała cele i zadania Ligi Kobiet i zgłosiła swój udział w jej pracy (APP, LK ZW, sygn. 2, k. 2). Statut Ligi Kobiet został uchwalony na II Krajowym Zjeździe w lipcu 1957 roku (ibidem, k. 1).Według zapisów statutowych Liga była organizacją kobiet zamieszkujących na terenie Polskiej Rzeczpospolitej Ludowej, prowadzącą działalność w celu:

„-- przyspieszenia rozwoju gospodarczego i kulturalnego Polski Ludowej, budującej socjalizm;

- umocnienia pokojowej i przyjaznej współpracy narodu polskiego z innymi narodami;

- umacniania więzów przyjaźni pomiędzy kobietami polskimi i kobietami innych krajów; 
- obrony i dalszego rozszerzania praw kobiet pracujących miast i wsi, żon, matek, obywatelek;

- organizowania społecznej inicjatywy kobiet dla lepszego wykorzystania wszystkich istniejących możliwości w szybszym poprawieniu warunków bytowych ludzi pracy miast i wsi;

- przełamywania szczególnych życiowych trudności kobiet i organizowania pomocy kobietom w następujących zagadnieniach:

a) zatrudnianiu kobiet, zgodnie $\mathrm{z}$ potrzebami gospodarki narodowej, zdobywaniu przez nie kwalifikacji zawodowych,

b) w wychowaniu dzieci, uczciwych i należycie przygotowanych do życia, gorących patriotów Polski Ludowej,

c) w wychowaniu kobiet na dobre gospodynie, umiejące sprawnie kulturalnie i oszczędnie prowadzić gospodarstwo domowe,

d) w podnoszeniu poziomu kulturalnego, etycznego i ideowego rodziny i społeczeństwa,

e) w podnoszeniu higieny i rozwijaniu zamiłowania do estetyki w ubieraniu, mieszkaniu i otoczeniu,

f) w podnoszeniu poziomu zdrowotnego kobiet" (ibidem, k. 1).

Kiedy czytamy założenia przedstawione w tym dokumencie, to rzucają się w oczy hasła odwołujące się do konieczności włączenia się w budowę państwa komunistycznego. Począwszy do modelowego wychowania „nowego obywatela”, po „uczciwą” pracę. Pojawia się element równouprawnienia, tylko, że on nie wynikał z szacunku i troski o kobietę, a z potrzeby władzy, która odbudowując kraj po zniszczeniach wojennych i odbudowując gospodarkę w ramach przyjętych wcześniej planów trzyletniego i sześcioletniego potrzebowała rąk do pracy. Oczywiście wśród haseł znajdują się również te odwołujące się do konieczności poprawy sytuacji bytowej kobiet, ale ta trudna sytuacja nie dotyczyła tylko kobiet, był to stan, który dotyczył całego społeczeństwa. Poziom życia Polaków w latach 40. i 50. był bardzo niski, dotyczyło to nie tylko aprowizacji rynku, ale prawie wszystkich sfer życia.

Realizacja zakładanych w statucie założeń miała pomóc w osiagnnięciu zadowalających wyników, jak to często podkreślano w nomenklaturze partyjnej, „na froncie” walki o lepsze życie obywateli, a tym samym miała w przyszłości skutkować „wzrostem młodego pokolenia ukształtowanego i oddanego partii” (Reczek, 2008b, s. 203).

Wypełnienie przyjętych celów Liga Kobiet chciała osiagnąć poprzez współpracę z instytucjami, organizacjami i zakładami pracy w zakresie działań określonych w statucie (APP, LKZW, sygn. 2, k. 1). 
Interesującym zapisem, który miał wskazywać na realny wpływ, jaki miała odgrywać Liga w kreowaniu życia kobiet w kraju była możliwość występowania do organów władzy państwowej z wnioskami dotyczącymi rozwiązywania żywotnych spraw kobiet (ibidem). Można jednak uznać, że władza poprzez swoje rozbudowane struktury władzy administracyjnej i partyjnej wiedziała, czego potrzebuje społeczeństwo. Kolejnym obszarem, w którym miała przejawiać się aktywizacja Ligi Kobiet była pomoc państwu w pracy oświatowo-wychowawczej, kulturalnej i opiekuńczej przez prowadzenie odpowiednich placówek, takich jak: świetlice dla dzieci, poradnie, internaty, uniwersytety wieczorowe dla kobiet, kluby dyskusyjne (ibidem). Do zadań Ligi należało również prowadzenie placówek ułatwiających kobietom przyswajanie właściwych metod prowadzenia gospodarstwa domowego, dbania o zdrowie, młodość, estetykę ubioru i mieszkań (ibidem). By umożliwić realizację tych postulatów powołano instytucje oraz podmioty, które miały ułatwić lub koordynować realizację tych zadań, były nimi m.in.: Komitet do Spraw Gospodarstwa Domowego, wypożyczalnie sprzętu gospodarstwa domowego, poradnie udzielające pomocy z zakresu robót ręcznych, prac domowych, higieny, kosmetyki itp. (ibidem).

Kobiety angażując się w budowanie „nowej socjalistycznej Polski” włączały się we współzawodnictwo pracy, wykonywały prace dotychczas zarezerwowane dla mężczyzn i wielokrotnie przekraczające ich możliwości fizyczne. Praca w ciężkich warunkach w fabrykach była codziennością. W swoich założeniach Liga chciała pomagać kobietom w zaspokajaniu ich potrzeb poprzez zakładanie i prowadzenie placówek gospodarczych i usługowych, w tym: jadłodajni, kwiaciarni, kawiarni, punktów usługowych itp. (ibidem).

Na terenie całej Polski zaczęły powstawać terenowe struktury Ligi Kobiet, poczynając od miast wojewódzkich, na wsiach kończąc. Podobnie sytuacja wyglądała w Wielkopolsce.

W Poznaniu działał Zarząd Wojewódzki Ligi Kobiet koordynujący i będący zarazem najwyższą instancją organizacji w regionie (APP, LKZW, sygn. 1, s. 1). Zadania Ligi w Poznaniu koordynował Zarząd Miejski Ligi Kobiet w Poznaniu, a w obrębie poszczególnych dzielnic działały Zarządy Dzielnicowe Ligi Kobiet - Stare Miasto, Nowe Miasto, Poznań Wilda, Poznań Jeżyce (ibidem, s. 35-44). Nad całością prac Ligi Kobiet w poszczególnych powiatach czuwały Zarządy Powiatowe (ibidem, s. 24-25).

Działalność w różnych okresach czasu nacechowana była zróżnicowaną dynamiką, która była wypadkową aktualnej sytuacji politycznej 
w kraju i aktywności samej organizacji. Wszystko to powodowało, że rozwój organizacji zależał od aktualnej wizji jej rozwoju przez władze w kontekście sytuacji politycznej i również w reakcji na działania samej Ligi.

Jak podaje Sławomira Walczewska „Liga Kobiet była uzależniona od PZPR nie tylko ideowo, lecz i organizacyjnie. W lutym 1966 roku droga odgórnej decyzji musiała zaprzestać działalności w zakładach pracy i z dnia na dzień z organizacji dwumilionowej stała się 70-tysięczną. Nie jest wykluczone, że była to kara za próbę krytyki polityki państwa wobec zatrudnienia kobiet: gdy w 1958 roku zwolniono z pracy 6 tys. kobiet w ramach tzw. „akcji porządkowania miejsc pracy”, Liga ujęła się za nimi i próbowała organizować je w spółdzielniach pracy. Jeśli był to akt niesubordynacji, to nigdy więcej już się nie powtórzył. Liga ograniczyła swoje ambicje do organizowania kursów kroju i szycia i stosownie do tego traciła swą atrakcyjność dla kobiet" (Walczewska, 2013).

Jej możliwości w terenie były jeszcze bardziej ograniczone i na przykład w woj. poznańskim główny ciężar prac Ligi Kobiet w Wielkopolsce polegał na podejmowaniu inicjatyw, mających na celu poprawę komfortu życia kobiet i ich rodzin (Reczek, 2008b, s. 204). Podczas posiedzenia Prezydium ZW LK w dniu 24 lutego 1962 roku przedstawiono problemy kobiet, a także sposoby ich rozwiązania, poruszane podczas III Zjazdu Ligi Kobiet, odbywającego się w dniach 17-19 lutego 1962 roku (APP, LK ZW, sygn. 27, s. 14-15). Dominowały sprawy bytowe, zauważono również konieczność podjęcia prób obniżenia cen sprzętu gospodarstwa domowego, mającego za zadanie ułatwienie pracy i skrócenie czasu przeznaczonego na zajęcia domowe kobietom pracującym zawodowo, ponieważ ze względu na jego wysokie ceny był on dla wielu pań niedostępny (ibidem, s. 14). Poruszono również konieczność zwiększenia dostępności asortymentu półfabrykatów przydatnych w kuchni, np. różnego rodzaju przetworów mięsnych, owocowych i warzywnych, które pozwoliłyby kobiecie w znacznie krótszym czasie przygotować posiłek dla siebie i swojej rodziny, ponieważ jak to tłumaczono: „czasochłonność prac domowych nie pozwała w takiej sytuacji kobietom na wypoczynek, rozrywkę i dokształcanie się" (ibidem). Niestety ze względu na trudności rynkowe wiele z podjętych prób poprawy komfortu życia z góry skazane było na niepowodzenie, ponieważ zaopatrzenie rynku w produkty spożywcze było niewystarczające w stosunku do potrzeb, jakie miało społeczeństwo. W tej sytuacji przyjmowanie takich deklaracji nie niosło za sobą realnych możliwości wpływania na zaopatrzenie sklepów i tym samym rzeczywis- 
te odciążenie kobiet, które musiały kreatywnie gospodarować tym, co znajdowały na pułkach sklepowych. Niemniej jednak niektóre z proponowanych rozwiązań wprowadzano $\mathrm{w}$ życie, tak było $\mathrm{z}$ uruchamianiem zbiorczych pralni w blokach (ibidem). Pomysł ten realizowany był zreszta przez całe dziesięciolecia i jeszcze na latach 90 . XX wieku budowano bloki, które były wyposażone w pralnie, co było realizacją założenia, że w znacznym stopniu ułatwią one prace, a tym samym przyczynią się do zmniejszenia hałasu w mieszkaniach, wywołanego przez pralki i wyeliminują proces nawilgacania (ibidem).

Codzienność miejska i wiejska, były to jednak dwie odmienne rzeczywistości i inne spojrzenia na sytuację kobiet. To co udawało się zyskać kobietom w mieście ze względu na fakt zamieszkiwania aglomeracji miejskiej, nawet w sytuacji kryzysu związanego z permanentną niewydolnością gospodarki komunistycznej, było przez wiele lat nieosiaggalne dla kobiet mieszkających na wsi. Mieszkańcy miast posiadali coraz większy dostęp do udogodnień związanych z rozwojem infrastruktury miejskiej i innymi udogodnieniami, natomiast przez długie lata pozbawieni tych udogodnień byli mieszkańcy wsi. Odmiennie w pewnym stopniu wyglądała sytuacja miasta i wsi w zakresie aprowizacji, tutaj wieś miała niewielką, ale przewagę nad miastem, ponieważ posiadanie skrawka ziemi, nawet $\mathrm{w}$ realiach państwa komunistycznego, biorąc pod uwagę kolektywizację wsi, walkę z kułakami, obowiązkowe dostawy kontyngentów rolnych, które były tak uciążliwe w latach 40. 50., to wraz z upływem czasu mamy do czynienia z sytuacją ,wyjazdu do rolnika” po bezpośredni zakup, nabiału lub innych produktów rolnych.

Sytuacja kobiet wiejskich stała się więc obszarem aktywności Ligi Kobiet. Feliks Woźniak - prezes Wojewódzkiego Związku Gminnych Spółdzielni zwracał uwagę, że: „brak jest wciąż na wsi punktów usługowych. Trudno jest na wsi naprawić pralkę, odkurzacz, nawet kontakt elektryczny. Sprawa pralni na wsi jest sprawą ważna, gdyż pralki domowe nie rozwiązują problemu w całości. Liczne rodziny, małe mieszkania i pralki domowe są trudne do pogodzenia" (APP, LKZW, sygn. 14, s. 4).

Zarząd Powiatowy Ligi Kobiet w Nowym Tomyślu zwracał uwagę, że Liga ,przez ostatnie lata skupiała głównie swoją działalność na pracy propagandowej, zebraniach poświęconych przede wszystkich omawianiu zagadnień politycznych, znanych już kobietom i naświetlonych w prasie i radio. Stopniowo Liga Kobiet wycofała się z wielu konkretnych form pracy i placówek prowadzonych w pierwszym okresie swej działalności, służącej zaspokajaniu codziennych potrzeb kobiet" (APP, LKZW, sygn. 304, k. 5). 
Wielokrotnie aktywność Ligi ogniskowała się na zagadnieniach politycznych. Była ona tubą propagandową władzy komunistycznej i realizowała założenia władzy mające na celu aktywizowanie kobiet w budowę państwa komunistycznego. Wraz z odwilżą październikową zmienia się postrzeganie roli kobiet zrzeszonych w Lidze Kobiet i dają one wyraz swojego niezadowolenia z panującej sytuacji społecznej i politycznej, podobnie jak uczyniło wiele innych środowisk politycznych i społecznych w Polsce.

Na tym samym posiedzeniu Zarządu Powiatowego Ligi w Nowym Tomyślu w odniesieniu do lat minionych mówiono: „nadmiernie w tym okresie wyrósł kult pracy zawodowej kobiet, przy jednoczesnej niesłusznej dewaluacji pracy w domu i w rodzinie, przy osłabieniu autorytetu dobrej, kulturalnej gospodyni domu. Brak szerszej aktywności Ligi Kobiet w walce o zaspokajanie codziennych potrzeb kobiet, był konsekwentnym następstwem źle pojętej roli organizacji kobiecej i wynikającymi stąd błędami jej programu" (ibidem). Idąc dalej potępiono promowany w okresie stalinowskim model kobiety pracującej i budującej socjalizm na równi z mężczyznami i wykonującej te same prace co mężczyźni. Odbywało się to nie w sferze ideologicznej, tylko ukazując jego bezsensowność jako działania mającego na celu realizację założeń władzy, uprzedmiotawiając kobietę i nie dbając o jej prawa i potrzeby i nie realizując tym samym idei równouprawnienia. „kierując kobiety do wszystkich tak zwanych zawodów męskich, brak odpowiednich kwalifikacji zawodowych kobiet, opieki i pomocy ze strony związków zawodowych i organizacji kobiecych, bez podjęcia poważnej pracy w kierunku złagodzenia trudu obowiązków domowych - nie przyniosły kobietom poważniejszych zwycięstw w realizacji równouprawnienia" (ibidem, s. 6).

Problemy kobiet poruszane były również podczas prac w Radach Narodowych wszystkich szczebli, w których uczestniczyły reprezentantki Ligi Kobiet. Współpraca z administracją miała się przyczynić do poprawienia trudnej sytuacji, szczególnie jeśli chodziło o kwestię poprawy zaopatrzenia sklepów, problemy mieszkaniowe i ogólną dostępność do usług tak w mieście, jak i na wsi (APP, KW PZPR, sygn. 1128, s. 67-68). Wielokrotnie poruszane tematy sygnalizowały tylko istniejące problemy, jednak ich doraźne rozwiązanie było niemożliwe ze względu na trudności gospodarcze i nawarstwiające się problemy związane z niedoborem wielu produktów, w tym szczególnie tych pierwszej potrzeby. Upływ lat z jednej strony powolnie ukazywał zachodzące zmiany, jednak przyrost naturalny, który wypełniał straty osobowe powstałe w trakcie drugiej wojny świato- 
wej, powodował, że trudno było zaspokoić potrzeby społeczeństwa w sytuacji funkcjonowania w realiach państwa komunistycznego i gospodarki socjalistycznej, która nie była w stanie zaspokoić stale rosnących potrzeb społeczeństwa.

Konieczność pracy zawodowej kobiet i łączenie tego z wychowaniem dzieci i prowadzeniem gospodarstwa domowego była trudnym zadaniem do realizacji. Liga Kobiet chcąc ulżyć kobietom wysunęła postulat zorganizowania klubów dziecięcych działających przed i popołudniu (APP, LKZW, sygn. 27, s. 14). Zaproponowano, by na ten cel zaadaptować niewykorzystywane w wielu zakładach pracy świetlice (ibidem, s. 14). Opiekunkami do dzieci miały być w nich emerytki (ibidem). Finansowanie klubów dziecięcych zostało złożone na zakłady pracy, na terenie których zorganizowano klub, a częściowo w kosztach miały partycypować związki zawodowe (ibidem). Pomysły te nie sprawdziły się, ich powszechna realizacja nigdy nie doszła do skutku. Kobietom pozostawała codzienna kreatywna organizacja czasu dnia.

Liga Kobiet starała się rozwiązywać problemy kobiet zapraszając do współpracy różne środowiska i instytucje. W roku 1962 prasa poznańska wspólnie z Zarządem LK zainicjowała akcję pod hasłem „Miesiąca Ewy” (ibidem, s. 15). Na łamach gazet ukazywały się artykuły, podejmujące aktualne sprawy kobiet (ibidem).

Wskazując na mankamenty swojej wcześniejszej aktywności Liga w coraz większym zakresie oddziaływała na kobiety mieszkające na wsi i zawiązywała współpracę z lokalnymi Kołami Gospodyń Wiejskich $(\mathrm{KGW})$, zajmując się kursami, które miały dać kobietom wiedzę i umiejętności związane z prowadzeniem gospodarstwa domowego i wyposażyć je w inne przydatne umiejętności. W roku 1963 na terenie Wielkopolski działało 1112 KGW zrzeszających 24164 członkiń (APP, LK ZW, sygn. 14, s. 15; APP, KW PZPR, sygn. 1137, s. 15-16). Od roku 1962 zorganizowały one dla kobiet 344 kursy żywieniowe, 155 kursów kroju i szycia, 348 kursów roślinnych i 316 hodowlanych (ibidem). Koła Gospodyń Wiejskich założyły 260 wypożyczalni sprzętu gospodarstwa domowego i przeprowadziły 234 kursów z zakresu oświaty sanitarnej, a także przeprowadziły na ten temat 1490 pogadanek (ibidem). Inicjatywy te miały na celu doskonalenie umiejętności wykonywania codziennych prac, a także podnosiły poziom świadomości kobiet, a za ich pośrednictwem rodzin i całej wsi.

Liga Kobiet i Koła Gospodyń Wiejskich starały się poprawić ogólny poziom życia kulturalnego mieszkanek wsi i w tym celu organizowano 
wycieczki krajoznawcze oraz imprezy artystyczne, czy wycieczki do teatru i kina (ibidem).

Na terenach wiejskich powiatowe komórki Ligi Kobiet we współpracę angażowały Państwowe Gospodarstwa Rolne (PGR) (APP, LK ZW, sygn. 14, s. 16). Sieć PGR i spółdzielni zalała wsie zgodnie z zamysłem odwzorowania modelu rolnictwa sowieckiego. Miejsca te stały się dużymi skupiskami kobiet z okolicznych terenów, które znajdowały w nich zatrudnienie. Podczas takich spotkań prowadzono kursy z zakresu gospodarstwa domowego, prelekcje i pogadanki na temat oświaty sanitarnej, wychowania, prawa i racjonalnego żywienia (APP, LK ZW, sygn. 14, s. 16; APP, KW PZPR, sygn. 1137, s. 15-16).

Pomoc dla kobiet zatrudnionych w PGR i spółdzielniach potrzebna była w okresach nasilonych prac polowych, wówczas opiekę nad dziećmi pracownic sprawowały tzw. „dziecińce” (APP, LK ZW, sygn. 14, s. 16). Na terenach wiejskich Liga Kobiet powiększała systematycznie swoje zaplecze, organizując: Zespoły Pracy Kobiet przy spółdzielniach mleczarskich, oraz Sekcje Kobiet przy Gminnych Spółdzielniach „Samopomoc Chłopska" (APP, KW PZPR, sygn. 1137, s. 15-16).

Przykładowo struktury Ligi Kobiet w powiecie nowotomyskim na przestrzeni lat ulegały stałemu wzrostowi. Jak podawano $\mathrm{w}$ jednym $\mathrm{z}$ dokumentów Zarządu Powiatu LK: „Zgodnie z założeniami statutu w naszym powiecie od 1945 r. istnieje i rozwija się masowa organizacja kobieca - Liga Kobiet, skupiająca w swych szeregach nie tylko kobiety z miasteczek, ale co ważniejsze ze wsi, gospodynie wiejskie, członkinie Kółek Rolniczych i Spółdzielni Produkcyjnych. Większość członkiń LK w miasteczkach naszego powiatu to robotnice i pracownice umysłowe zatrudnione we wszystkich niemal zakładach pracy. Nikły procent członkiń stanowią kobiety gospodynie domowe, nie pracujące zawodowo oraz inteligencja zawodowa (lekarki, nauczycielki, inżynierowie). Jeśli porównamy stan członkiń i kół w powiecie z lat 1945-1946, ze stanem z roku bieżącego 1961, to zauważymy wyraźnie, że nasza organizacja rozbudowała się zwiększając swe szeregi wielokrotnie. 1945-1946 liczba kół 3, ilość członkiń 48; w latach 1947-1950 liczba kół 5, członkiń 138; a w kwietniu 1961 r. liczba kół 14, a liczba członkiń 830" (APP, LK ZW, sygn. 304, k. 37).

Wzrost liczby kół Ligi Kobiet na terenach wiejskich i w miastach powodował zwiększenie aktywności struktur terenowych i zwiększenie aktywności mającej na celu troskę o życie codzienne kobiet. Zmianie uległ ciężar i nacisk na aspekty pracy z kobietami. Powoli odchodził model 
Polki jako pracownicy i władza dostrzegała potrzeby kobiet związane z realizacją zawodową i rodzinną. Niemniej jednak Liga Kobiet cały czas podejmowała zakrojone na dużą skalę inicjatywy, mające służyć kształtowaniu i wychowaniu kobiet na dobrego obywatela, ukazując wkład kobiet w budowanie socjalizmu, połączone z ,harmonijnym” życiem prywatnym. Miejscem takiej obecności były m.in. zakłady pracy, choć odbywało się to w ograniczonym zakresie. W latach 1953-1957 Liga wycofała się z zakładów, w których jej rolę miały przejąć związki zawodowe (APP, KW PZPR, sygn. 1131, s. 69-70). Nie prowadziły one jednak tej działalności w sposób należyty, ponieważ realizowały inne założenia statutowe, dlatego w drugiej połowie roku 1957 ponownie rozpoczęto organizowanie Kół Ligi Kobiet w Zakładach, w oparciu o które następnie Związki Zawodowe powołały Komisje Kobiece (ibidem).

Formy aktywności kobiet w latach sześćdziesiątych były najróżniejsze i związane były one z ich aktywnością zawodową lub środowiskiem, w którym funkcjonowały. Nie było sfery, w której aktywność Ligi Kobiet nie mogłaby zaistnieć. W Miejskim Zarządzie LK w Pile, zorganizowano kobiece drużyny ORMO, kontynuacją tych działań na szczeblu oficjalnym było powołanie 12 maja 1969 r. Zespołu ds. Kół Rodziny Milicyjnej, co było wynikiem podpisanego porozumienia pomiędzy Zarządem Głównym Ligi Kobiet i Ministerstwem Spraw Wewnętrznych (APP, LK ZW, sygn. 14, s. 24; APP, LK ZW, sygn. 28, s. 78).

Na szczeblu województwa w Poznaniu 20 lutego 1968 r. podpisane zostało porozumienie pomiędzy Zarządem Wojewódzkim Ligi Kobiet w Poznaniu i Zarządem Wojewódzkim Ligi Obrony Kraju w Poznaniu (APP, LK ZW, sygn. 28, s. 17-18). Celem porozumienia było rozwijanie idei społecznej działalności obronnej wśród kobiet (APP, LK ZW, sygn. 28, s. 10). W jego założeniach leżała „popularyzacja wśród kobiet postępowych tradycji narodu i oręża polskiego", jak również przygotowanie kobiet do pełnienia służby pomocniczej na wypadek zagrożenia (ibidem).

12 maja 1969 roku zawarto pomiędzy ZW LK i Zarządem Wojewódzkim Poznańskiego Towarzystwa Krzewienia Kultury Fizycznej porozumienie w sprawie współpracy nad rozwijaniem działalności sportowo-rekreacyjnej dzieci i rodzin w miejscu zamieszkania (APP, LK ZW, sygn. 28, s. 107). Stawiano sobie za cel kształtowanie i umacnianie poprzez sport i wychowanie fizyczne ,zasad dyscypliny i solidarności oraz wypełniania obowiązków społecznych i obywatelskich” (ibidem). Zakładano również „zacieśnianie poprzez wspólną działalność sportowo-rekreacyjną więzi społecznej wśród ogółu mieszkańców bloków i osiedli miejskich” (ibidem). 
Była to aktywność charakterystyczna dla modelu ówczesnego państwa komunistycznego, w którym grupy zawodowe czy społeczne włączały się, ukazując w ten sposób swoją odpowiedzialność i zaangażowanie oraz troskę o „dobro” kraju. Wszechobecne czyny społeczne, współzawodnictwo zawodowe miały pokazać masowe zaangażowanie w budowanie ustroju socjalistycznego, według takiego schematu funkcjonowały i wpisywały się w niego poczynania Ligi Kobiet.

Prowadzenie tak szeroko zakrojonej działalności przez Ligę Kobiet wypełniało wszystkie sfery aktywności kobiet. Liga Kobiet nie przejawiała dużej aktywności stricte politycznej, co już zostało przywołane, chociaż ze względu na swój publiczny charakter i liczną bazę społeczną, była uczestnikiem życia politycznego.

Główny ciężar tej działalności zajmowała aktywność członkiń Ligi Kobiet w pracach Rad Narodowych wszystkich szczebli oraz podczas kampanii wyborczych do tychże rad i Sejmu (APP, LK ZW, sygn. 24, 64, $66,68,70,72)$.

Mimo akcji agitacyjnej prowadzonej wśród kobiet wyniki wyborów były efektem ustaleń partyjnych i wskazania kandydatur przez Polską Zjednoczoną Partię Robotniczą (PZPR), a nie wyborów, według zasad demokratycznych, jakie znamy obecnie. Wskazanie przez władze kobiet zaangażowanych w działalność społeczną lub polityczną dawało mandat do zasiadania w radach lub ławach sejmowych. W Sejmie II kadencji lat 1957-1961 nie było żadnej kobiety z terenu Wielkopolski, a w radach narodowych wszystkich szczebli zasiadały tylko 893 kobiety (APP, LK ZW, sygn. 68, s. 6). W następnej kadencji do Sejmu weszły z Wielkopolski 4 kobiety, a w radach zasiadało ich 2158 (ibidem). W Sejmie IV kadencji było 5 kobiet $\mathrm{z}$ województwa poznańskiego, a w skład rad narodowych wybrano 2186 kobiet (APP, LK ZW, sygn. 70, s. 16). Sejm V kadencji lat 1969-1973 obradował z udziałem 4 kobiet z województwa poznańskiego, a rady w swych szeregach miały 2453 radne (APP, LK ZW, sygn. 72, s. 69).

Aktywność polityczna kobiet zaangażowanych w prace na rzecz kobiet była marginesem tej działalności. Największy obszar aktywności Ligi to praca nad rozwiązywaniem codziennych spraw kobiet. Liga Kobiet była jednak przybudówką władz i jako taka musiała realizować zadania i linię polityczną partii. Szczególne znaczenie miała aktywność propagandowa i ukazywanie sukcesów władzy lub popieranie polityki partii w sytuacjach kryzysów lub w związku z ustaleniami kolejnych zjazdów partii.

Przedstawicielki kobiet zabierały głos za pośrednictwem Ligi Kobiet w momentach szczególnych, podczas ważnych wydarzeń politycznych, 
jak choćby wydarzenia Marca 1968 roku (Reczek, 2008b, s. 209). Przewodnicząca ZW LK w Poznaniu Maria Roszczak wystosowała list do I sekretarza KC PZPR Władysława Gomułki, popierający politykę partii i domagający się równoczesnego oczyszczenia partii i rządu oraz organizacji społecznych z elementów wrogich i syjonistycznych (APP, LK ZW, sygn. 28, s. 39). Takie stanowisko było odzwierciedleniem panujących wówczas stosunków politycznych. Podczas posiedzenia Prezydium ZW LK, w dniu 24 kwietnia 1968 roku, odniosło się negatywnie, jak to zostało określone, do „wrogich” wystapień przeciw polityce partii i ustrojowi socjalistycznemu oraz udzieliło całkowitego poparcia dla polityki partii i „towarzysza Wiesława jej czołowego przywódcy" (APP, LK ZW, sygn. 28, s. 34).

Specyfika okresu Polski Ludowej powodowała, że nie było możliwości powoływania organizacji i stowarzyszeń, które byłyby niezależne od władzy komunistycznej i mogłyby rzeczywiście reprezentować interesy swoich członków. Funkcjonująca w takich realiach Liga Kobiet, nawiązująca do tradycji kobiecych okresu międzywojennego, choć de facto ich nie realizująca, cały czas rosła w siłę.

Zarząd Powiatowy Ligi Kobiet w Nowym Tomyślu w swych dokumentach zapisał: „Ostatnio trzeba stwierdzić, że ranga społeczna naszej organizacji znowu się podniosła. Członkinie Ligi Kobiet i nie członkinie coraz bardziej przekonują się do Ligi ufając, że organizacja stanie zawsze w obronie praw kobiety, pomoże i doradzi w rozwiązywaniu całego splotu problemów, ba nawet drobnych kłopotów jakie niesie za sobą życie" (APP, LK ZW, sygn. 304, k. 42).

Trudno jednoznacznie ocenić działalność Ligi Kobiet w omawianym okresie. Funkcjonowała ona w specyficznych warunkach państwa komunistycznego, co więcej jej powstanie było już powiązane ze strukturami państwa komunistycznego i za cel miało pozyskanie środowisk kobiecych, z jednej strony do legitymizowania władzy, a z drugiej strony do wyeliminowania innych środowisk kobiecych, oddając Lidze monopol reprezentowania kobiet $\mathrm{z}$ akceptacją władzy i zgodnie z jej polityką.

Mimo wszystko, pamiętając o wszystkich negatywnych aspektach działalności Ligi Kobiet, które były uwarunkowane złożonością sytuacji politycznej w Polsce, Liga zrobiła niemało by poprawić sytuację kobiet.

\section{Bibliografia}

Archiwum Państwowe w Poznaniu (dalej: APP), Liga Kobiet Zarząd Wojewódzki w Poznaniu (dalej LK ZW), sygn. 2, Statut Ligi Kobiet. 
APP, LK ZW, sygn. 1, Wykaz założycielek Ligi Kobiet na terenie województwa poznańskiego.

APP, LK ZW, sygn. 14, Protokół posiedzenia Prezydium Zarządu Wojewódzkiego Ligi Kobiet w Poznaniu z dnia 24.05.1963 r.

APP, LK ZW, sygn. 14, Protokół plenarnego zebrania Zarządu Wojewódzkiego Ligi Kobiet w Pile z dnia 25.12.1963 r.

APP, LK ZW, sygn. 24, 64, 66, Konferencje sprawozdawczo-wyborcze ZW LK w Poznaniu, II Wojewódzka Konferencja Wyborcza ZW.

APP, LK ZW, sygn. 27, Protokół posiedzenia Prezydium Zarządu Wojewódzkiego Ligi Kobiet w Poznaniu z dnia 24.02.1962 r.

APP, LK ZW, sygn. 28, Protokół posiedzenia Prezydium Zarządu Wojewódzkiego Ligi Kobiet w Poznaniu z dnia 8.02.1968 r.

APP, LK ZW, sygn. 28, Protokół wspólnego posiedzenia Prezydium Zarządu Wojewódzkiego Ligi Kobiet w Poznaniu i Zarządu Wojewódzkiego Ligi Obrony Kraju w Poznaniu z dnia 20.02.1968 r.

APP, LK ZW, sygn. 28, Protokół posiedzenia Prezydium Zarządu Wojewódzkiego Ligi Kobiet w Poznaniu z dnia 10.04.1968 r.

APP, LK ZW, sygn. 28, Protokół posiedzenia Prezydium Zarządu Wojewódzkiego Ligi Kobiet w Poznaniu z dnia 24.04.1968 r.

APP, LK ZW, sygn. 28, Porozumienie zawarte między ZW LK w Poznaniu a ZW Poznańskiego Towarzystwa Krzewienia Kultury Fizycznej.

APP, LK ZW, sygn. 28, Protokół posiedzenia Prezydium Zarządu Wojewódzkiego Ligi Kobiet w Poznaniu z dnia 13.03.1969 r.

APP, LK ZW, sygn. 68, Konferencja sprawozdawczo-wyborcza ZW LK w Poznaniu $\mathrm{z}$ dnia 24.05.1961 r.

APP, LK ZW, sygn. 70, Konferencja sprawozdawczo-wyborcza ZW LK w Poznaniu $\mathrm{z}$ dnia 26.04.1966 r.

APP, LK ZW, sygn. 72, Konferencja sprawozdawczo-wyborcza ZW LK w Poznaniu $\mathrm{z}$ dnia 28.04.1970 r.

APP, LK ZW, sygn. 304, Protokoły z posiedzeń oraz sprawozdania z działalności Zarządu Powiatowego w Nowym Tomyślu 1958-1965.

APP, KW PZPR, sygn. 1128, Informacja z dnia 21 lipca 1961 roku o udziale kobiet w pracach Rad Narodowych.

APP, KW PZPR, sygn. 1131, Informacja z dnia 30 stycznia 1962 roku o niektórych wypowiedziach i komentarzach związanych z Krajowym Zjazdem Ligi Kobiet.

APP, KW PZPR, sygn. 1137, Informacja z dnia 12 lipca 1963 roku o działalności kobiet wiejskich ze szczególnym uwzględnieniem działalności kulturalno-oświatowej.

Klepacz A. (2013), Historia - Liga Kobiet Polskich ma sto lat, http://ligakobietpolskich.pl/?page_id=146, 8.09 
Kumor B. (2001), Historia Kościoła, Lublin.

Łatyński M. (2002), Nie paść na kolana. Szkice o polskiej polityce lat powojennych, Wrocław.

Od niepodległości do niepodległości. Historia Polski 1918-1989(2010), red. A. Dziurok, M. Gałęziowski, Ł. Kamiński, F. Musiał, Warszawa.

Reczek R. (2008a), Propaganda antykomunistyczna na łamach poznańskich periodyków, w: Władze wobec Kościołów i zwiazków wyznaniowych $w$ Wielkopolsce w latach 1945-1956, red. K. Białecki, Poznań.

Reczek R. (2008b), Życie społeczno-polityczne w Wielkopolsce w latach 1956-1970, Poznań.

Stanisław Mikołajczyk w dokumentach aparatu bezpieczeństwa (2010), t. 1, red. wstęp J. Gmitruk, Warszawa.

Walczewska S., Liga Kobiet - jedyna organizacja kobieca w PRL, http://www.efka.org.pl/index.php?action=p_art\&ID=2, 8.09.2013.

Wybory do Sejmu z 19 stycznia 1947 roku w województwie poznańskim. Wybór źródet (2010), wstęp P. Orzechowski, Poznań.

\section{The Women's League as an organization 'representing' women's interests in Communist Poland. An outline of activities}

\section{Summary}

The end of WWII did not bring the freedom Poles had desired so much. The activities of the Communist authorities right after the war resulted from their weakness. Their operations were initially possible thanks to the Red Army, and later on due to the extensive repression system of a Communist state. Under such political circumstances, only political parties and other entities that submitted to the Communist authorities and did not attempt to set new directions or political and social trends were allowed to operate. Operating in the reality of a Communist state, they complied with the vision propagated or recommended as appropriate by the Communist authorities. This was the case of the Women's League. Established in August 1945, the League was among the first organizations formally registered after the war. It is difficult to evaluate the activities of the Women's League in the period discussed. The organization operated under the peculiar conditions of a Communist state; what is more, its emergence was even initiated by the structures of this state, aimed at winning over women's circles in order to legitimize the authorities on the one hand, and to eliminate other women's organizations, thus giving the League the exclusive right to represent women, as approved by the authorities and in line with their policy. Bearing in mind all the negative aspects of the activities of the Women's League, which stemmed from the complex political situation in Poland, the organization made a considerable effort to improve the situation of women. 